\title{
PENGEMBANGAN KOMPETENSI SUMBER DAYA MANUSIA DALAM MENINGKATKAN PELAYANAN PADA PELAKU USAHA DI KABUPATEN BULUKUMBA
}

\author{
The Development of Human Resources Competency in ImprovingServices to Businessmen in \\ Bulukumba Regency
}

\author{
Nurintan Madduppa ${ }^{1}$, Juharni ${ }^{2}$, Syamsuddin Maldun ${ }^{2}$ \\ ${ }^{1}$ Dinas Penanaman Modal dan Pelayanan Terpadu Satu Pintu Kabupaten Bulukumba, Sulawesi Selatan \\ ${ }^{2}$ Program Studi Ilmu Administrasi Negara, Program Pascasarjana, Universitas Bosowa \\ Email: nurintanmadduppa1973@gmail.com
}

Diterima: 22 Agustus 2020

Dipublikasikan: 07 Desember 2020

\begin{abstract}
ABSTRAK
Sumber Daya Manusia adalah suatu hal yang penting dalam usaha apapun karena kualitas dari hal tersebut sangatlah menentukan kinerja dari suatu perusahaan atau organisasi. Pengelolaan dan pengembangan Sumber Daya Manusia merupakan suatu investasi bagi perusahaan maupun organisasi karena diperlukan biaya untuk mewujudkan hal tersebut, namun sejalan dengan hal tersebut, manfaat yang didapat dari perusahaan maupun organisasi juga besar dikarenakan karyawan ataupun pegawai yang dimiliki menjadi lebih profesional dan handal dalam mengerjakan segala pekerjaan dibidangnya. Adapun tujuan daripada penelitian ini tidak terlepas dari rumusan masalah sebagaimana yang telah dibuat, yaitu untuk mengetahui dan menganalisis proses pengembangan sumber daya manusia dalam pelayanan terhadap pelaku usaha, juga mengetahui dan menganalisis tantangan pelaksanaan pengembangan kompetensi sumber daya manusia, serta implikasi pengembangan SDM di DPMPTSP Kabupaten Bulukumba. Pada penulisan ini metode pendekatan yang dilakukan adalah peneliti membuat suatu gambaran kompleks, meneliti kata-kata, laporan terinci dari pandangan responden, dan melakukan studi pada situasi yang alami. Penelitian ini adalah penelitian kualitatif yang menggunakan pendekatan deskriptif analitis, mengingat metode ini digunakan untuk meneliti kejadian-kejadian yang sedang berlangsung dan berhubungan dengan kondisi pada masa sekarang. Penelitian ini menggunakan analisis data kualitatif dengan pendekatan induktif dengan cara menarik kesimpulan dari data yang ada. Artinya dengan bertolak dari fakta di lapangan, penulis mencoba menggali informasi dan data empiris untuk membangun teori. Data yang diperoleh dari hasil wawancara dan pengamatan dilapangan diolah oleh penulis sebelum analisis data dilakukan. Semua data tersebut kemudian ditafsirkan dan dianalisis secara induktif. Dari hasil penelitian ini disimpulkan, melalui pengembangan sumber daya manusia juga membantu menciptakan budaya efisiensi dalam organisasi khususnya terhadap Dinas Penanaman Modal dan Pelayanan Terpadu Satu Pintu (DPMPTSP) Kabupaten Bulukumba. Hal ini mengarah pada efektivitas organisasi yang lebih besar. Dengan dukungan sarana dan prasarana serta kerjasama tim dengan OPD terkait, sumber daya dimanfaatkan dengan baik dan tujuan serta target dicapai dengan cara yang lebih baik.
\end{abstract}

Kata Kunci: Implementasi, Kompetensi, Sumber Daya Manusia, Pelayanan, Bulukumba

\begin{abstract}
Human Resources are an important thing in any business because the quality of these matters greatly determines the performance of a company or organization. The management and development of Human Resources is an investment for companies and organizations because it requires costs to make this happen, but in line with this, the benefits obtained from companies and organizations are also large because their employees become more professional and reliable in doing every work in their field. The purpose of this research is inseparable from the research question that has been made, which is to find out and analyze the process of human resource development in services to businessmen, as well as to know and analyze the challenges of implementing human resource competency development, as well as implications of HR development in DPMPTSP Bulukumba Regency. In this writing, the approach method used is that the researcher makes a complex picture, examines words, reports in detail from the views of the respondents, and conducts studies on natural situations. This research is a qualitative research that uses a descriptive analytical approach, considering that this method is used to examine ongoing events and related conditions in the present. This study uses qualitative data analysis with an inductive approach by drawing conclusions from existing data. This means that by starting from factual information, the writer tries to dig up empirical information and data to build a theory. The data obtained from interviews and observations were processed by the author before data analysis was carried out. All data is then interpreted and analyzed inductively. From the results of this study, it was concluded that through human resource development, this helps to create a culture of efficiency in the organization, especially in Investment and One Stop Services Office (DPMPTSP) Bulukumba Regency. This leads to greater organizational effectiveness. With the support of facilities and infrastructure and teamwork with related DPOs, resources are used well, and goals as well as targets are achieved in a better way.
\end{abstract}

Keywords: Comptenece, Human Resource, Service, Bulukumba 


\section{PENDAHULUAN}

Pengelolaan dan pengembangan sumber daya manusia menjadi penentu keberhasilan dari suatu organisasi atau perusahaan. Pemberian pelayanan pada masyarakat secara maksimal dan professional akan mengakibatkan kepuasan yang diterima oleh masyarakat ataupun pelaku usaha yang bermohon perbitan izin. Dalam arti lain, bahwa pengelolaan sumber daya manusia dengan berdayaguna akan mampu mencapai tujuan organisasi.

Kompetensi didefinisikan oleh Mitrani (1995) sebagai suatu sifat dasar seseorang yang dengan sendirinya berkaitan dengan pelaksanaan suatu pekerjaan secara efektif (and underlying charactheristic: of an individual which is casually related to effective or superior performance in job), Ketidaksamaan dalam kompetensi-kompetensi inilah yang membedakan seseorang pelaku unggul dari perilaku yang berprestasi rata-rata. Untuk mencapai kinerja sekedar cukup atau rata-rata, diperlukan kompetensi batas (threshold competemcies) atau kompetemsi essensial. Pendidikan dan latihan berpengaruh positif dan signifikan pengembangan SDM pada Dinas Kepariwisataan Kabupaten Kepulauan Selayar. Lingkungan kerja berpengaruh positif terhadap pengembangan SDM pada Dinas Kepariwisataan Kabupaten Kepulauan Selayar (Handayani et. al , 2021)

Kompetensi batas atau kompetensi istimewa untuk suatu pekerjaan tertentu merupakan pola atau pedoman dalam pemilihan karyawan (personel selection), Perencanaan pengalihan tugas (succestion planing), peniliaian kinerja (performance appaisal), dan pengembangan. Kompetensi erat kaitannya dengan kinerja, baik kinerja individu maupun kinerja organisasi (perusahaan). Menurut Amstrong (1994) kinerja seseorang didasarkan pada pemahaman ilmu pengetahuan, keterampilan, keahlian dan perilaku yang diperlukan untuk melakukan pekerjaan dengan baik. Sedangkan kinerja organisasi (perusahaan) didasarkan pada bagaimana manajemen perusahaan merespon kondisi eksternal dan internalnya, yang dengan tolok ukur tertentu akan dapat diketahui berapa tingkat turbelensinya dan berapa tingkat kemampuan untuk mengantisipasinya. Schermerhornet al. juga mengemukakan bahwa "Performance is formally defined as the quantity and quality of task accomplishment individual, group, or organizational" (Tobing, 2009). Simamora mengemukakan bahwa "Kinerja karyawan (employee performance) adalah tingkat pada tahap mana para karyawan mencapai persyaratan-persyaratan pekerjaan" (Tobing, 2009).

Di samping itu, Robbins (2008) mengemukakan bahwa kinerja karyawan merupakan fungsi dari interaksi antara kemampuan (ability), motivasi (motivation), dan kesempatan (opportunity). Dari beberapapendapatdapat disimpulkan bahwa kinerja merupakan suatu konsep yang bersifat universal yang merupakan efektivitas operasionalsuatu organisasi, bagian organisasi dan bagian karyawannya berdasarkan standard dan kriteria yang telah ditetapkan sebelumnya, karena organisasi pada dasarnya dijalankan oleh manusia, maka kinerja sesungguhnya merupakan perilaku manusia dalam memainkan peran yang mereka lakukan di dalam suatu organisasi untuk memenuhi standard perilaku yang telah ditetapkan agar membuahkan tindakan dan hasil yang diinginkan (Winardi, 1992).

Manajemen Sumber Daya Manusia merupakan salah satu bidang strategis dari organisasi. Jeffrey Pfeffer dalam Sutrisno (2010) berargumentasi bahwa Sumber Daya Manusia (selanjutnya disebut SDM) merupakan sumber keunggulan daya saing yang mampu menghadapi tantangan. Agar suatu organisasi mampu terus bertahan dan bersaing, dominasi teknologi saja tidak cukup jika tidak ditunjang oleh sumber daya manusia yang unggul. SDM dalam suatu organisasi yang dapat diandalkan untuk menggerakkan sumber daya lainnya dalam mewujudkan keunggulan bersaing adalah SDM yang mampu mengembangkan diri secara proaktif, yang mau belajar, mau bekerja keras dengan penuh semangat, dan mau bekerja sama. SDM yang dibutuhkan organisasi adalah SDM yang sanggup menguasai teknologi dengan cepat, adaptif, responsif, terhadap perubahan-perubahan teknologi dan memiliki sikap melayani serta berintegritas tinggi.

Penulis yang juga merupakan pegawai pada Dinas Penanaman Modal dan Pelayanan Terpadu Satu Pintu (DPMPTSP) Kabupaten Bulukumba setelah melihat dan meneliti lingkup kerja yang dilakukan mulai pada bulan Februari hingga Mei 2020, bahwa timbulnya keluhan di tengah masyarakat terkait pemberian izin yang terkadang lamban dalam proses serta tidak cermatnya para pengelola pemberi izin disamping masih banyaknya usaha-usaha yang beroperasi di Kota Bulukumba belum memiliki izin yang berakibat rendahnya capaian target penerimaan Pendapatan Asli Daerah (PAD) dari sektor izin usaha.

Tujuan penelitian adalah (1) Untuk mengetahui dan menganalisis proses pengembangan sumber daya manusia dalam pelayanan terhadap pelaku usaha di DPMPTSP Kabupaten Bulukumba; (2) Untuk mengetahui dan menganalisis tantangan pelaksanaan pengembangan kompetensi sumber daya manusia di DPMPTSP Kabupaten Bulukumba; dan, (3) Untuk mengetahui dan menganalisis implikasi pengembangan SDM di DPMPTSP Kabupaten Bulukumba.

\section{METODE}

Penelitian ini adalah penelitian kualitatif yang menggunakan pendekatan deskriptif analitis, mengingat metode ini digunakan untuk meneliti kejadian-kejadian yang sedang berlangsung dan berhubungan dengan kondisi pada masa sekarang. Sementara lokasi penelitian terletak di Dinas Penanaman Modal dan Perizinan Terpadu Satu Pintu yang beralamat Jalan Kenari Nomor 13 Kelurahan Loka Kecamatan Ujung Bulu Kabupaten 
Bulukumba, dan waktu penelitian dilaksanakan pada bulan Februari hingga Mei 2020.

Instrumen penelitian dalam tradisi penelitian kualitatif adalah manusia/orang yakni peneliti sendiri dengan menggunakan alat bantu berupa catatan, tape recoreder, dan tustel (camera). Catatan, tape recoreder, dan tustel (camera) hanya digunakan sebagai alat bantu dalam melakukan penelitian. Sementara guna mendapatkan data penelitian yang akurat, maka peneliti (human instrument) harus berperan serta (participant observation) dan melakukan wawancara mendalam (in dept interview) dengan sumber data

Adapun metode pengumpulan data yang digunakan pada penulisan ini adalah : Observasi, Wawancara, dan Dokumentasi. Penulis juga mengumpulkan beberapa dokumen penting seperti : buku-buku notulensi, makalah, peraturan-peraturan, bulletin-buletin, catatan harian dan sebagainya, dengan tujuan untuk melengkapi data-data yang diinginkan (Suharsini. A, 1993). Sebagaimana dikutip Sugiyono dari Miles dan Huberman, bahwa analisis data dilakukan sepanjang proses penelitian berjalan. (Sugiyono, 2015). Analisis data yang dilakukan secara berulang dan kontinyu, nantinya akan mendapatkan hasil yang lebih akurat.

Peneliti menggunakan deskriptif yang bersifat eksploratif, yaitu dengan menggambarkan keadaan atau status fenomena. (Suharsini. A, 1993). Pada intinya, penulis hanya ingin mengetahui hal-hal yang berhubungan dengan keadaan sesuatu, namun tetap berusaha untuk memecahkan persoalan-persoalan yang ada dalam rumusan masalah dan cara menganalisa datadata yang diperoleh.

\section{HASIL DAN PEMBAHASAN}

Gambaran Umum Dinas Penanaman Modal dan Pelayanan Terpadu Satu Pintu Kabupaten Bulukumba

Dinas Penanaman Modal dan Pelayanan Terpadu Satu Pintu (DPMPTSP) Kabupaten Bulukumba dibentuk berdasarkan Peraturan Bupati Bulukumba Nomor 83 Tahun 2016 tentang Kedudukan, Tugas dan Fungsi, Susunan Organisasi, dan Tata Kerja Dinas Penanaman Modal dan Pelayanan Terpadu Satu Pintu Kabupaten Bulukumba.

Penyelenggaraan PTSP, DPMPTSP Kabupaten Bulukumba diberikan kewenangan untuk menerbitkan izin dan non izin berdasarkan : (1) Peraturan Bupati Bulukumba Nomor 88 Tahun 2015 tentang Penyelenggaraan Perizinan dan Non Perizinan Terpadu Satu Pintu Pemerintah Kabupaten Bulukumba; (2) Peraturan Bupati Bulukumba Nomor 49 Tahun 2017 perubahan atas Peraturan Bupati Nomor 88 Tahun 2015 tentang Penyelenggaraan Perizinan dan Non Perizinan Terpadu Satu Pintu Pemerintah Kabupaten Bulukumba;

Dalam hal menjalankan tugas dan fungsinya, DPMPTSP Kabupaten Bulukumba mempunyai Visi yaitu : mewujudkan pelayanan prima dalam mendukung penyelenggaraan pemerintahan daerah, sementara Misi yang diemban adalah meningkatkan sarana dan prasarana pelayanan, meningkatkan kualitas SDM aparat pelayanan, dan meningkatkan mutu dan kepuasan pelayanan.

Untuk itu dalam rangka menjalankan tugas dan fungsinya selaku Organisasi Perangkat Daerah (OPD) Lingkup Penanaman Modal dan Pelayanan Terpadu Satu Pintu (PM-PTSP), DPMPTSP Kabupaten Bulukumba mengelola anggaran Dana Alokasi Umum (DAU) sebagaimana yang tertuang dalam Dokumen Pelaksanaan Anggaran Satuan Kerja Perangkat Daerah (DPA-SKPD), dan untuk lebih jelasnya dapat diuraikan pada table berikut ini:Hasil penelitian disajikan dengan lengkap dan sesuai ruang lingkup penelitian. Hasil penelitian dapat dilengkapi dengan tabel, grafik (gambar), dan/atau bagan. Tabel dan gambar diberi nomor dan judul. Hasil analisis data dimaknai dengan benar.

Tabel 1. Besaran Nilai Anggaran Pada DPMPTSP Kab. Bulukumba Tahun Anggaran 2020

\begin{tabular}{lccc}
\hline $\mathbf{N}$ & Uraian & Anggaran (Rp.) & $\%$ \\
o. & & & \\
\hline 1. & Belanja Tidak Langsung : & & \\
& $\Rightarrow \quad$ Belanja Pegawai & $2.753 .347 .899,00,-$ & 64,57 \\
& & & \\
\hline
\end{tabular}

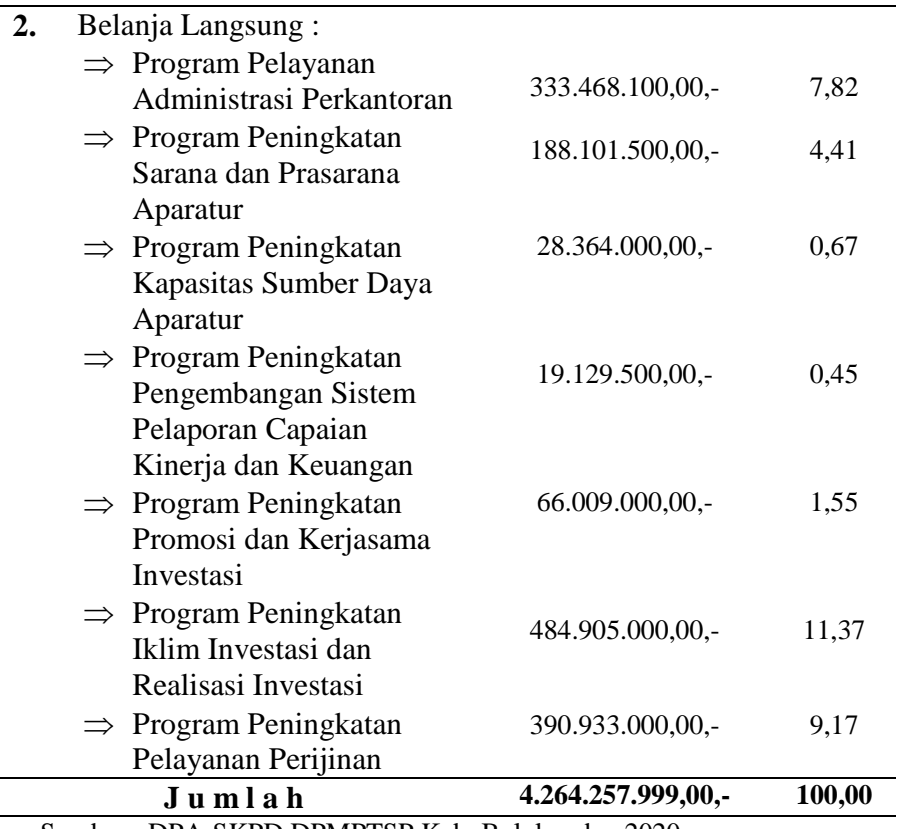

Sumber : DPA-SKPD DPMPTSP Kab. Bulukumba, 2020

Sementara untuk besaran nilai anggaran dilihat dari Belanja Langsung pada Tahun 2020 adalah Rp. 1.510.910.100,00,- (Satu Milyar Lima Ratus Sepuluh Juta Sembilan Ratus Sepuluh Ribu Seratus Rupiah) sebagaimana dimaksud dapat diuraikan pada table berikut ini: 
Tabel 2. Besaran Nilai Anggaran Pada DPMPTSP Kab. Bulukumba Khusus Belanja Langsung Tahun Anggaran 2020

\begin{tabular}{|c|c|c|c|}
\hline No & Uraian & Anggaran (Rp.) & $\%$ \\
\hline \multirow[t]{8}{*}{1.} & $\begin{array}{l}\text { Belanja Langsung: } \\
\Rightarrow \text { Program Pelayanan } \\
\text { Administrasi } \\
\text { Perkantoran }\end{array}$ & $333.468 .100,00,-$ & 22,07 \\
\hline & $\begin{aligned} \Rightarrow & \text { Program Peningkatan } \\
& \text { Sarana dan Prasarana } \\
& \text { Aparatur }\end{aligned}$ & 188.101.500,00,- & 12,45 \\
\hline & $\begin{aligned} \Rightarrow & \text { Program Peningkatan } \\
& \text { Kapasitas Sumber } \\
& \text { Daya Aparatur }\end{aligned}$ & 28.364.000,00,- & 1,88 \\
\hline & $\begin{aligned} \Rightarrow & \text { Program Peningkatan } \\
& \text { Pengembangan } \\
& \text { Sistem Pelaporan } \\
& \text { Capaian Kinerja dan } \\
& \text { Keuangan }\end{aligned}$ & 19.129.500,00,- & 1,27 \\
\hline & $\begin{aligned} \Rightarrow & \text { Program Peningkatan } \\
& \text { Promosi dan } \\
& \text { Kerjasama Investasi }\end{aligned}$ & 66.009.000,00,- & 4,37 \\
\hline & $\begin{aligned} \Rightarrow & \text { Program Peningkatan } \\
& \text { Iklim Investasi dan } \\
& \text { Realisasi Investasi }\end{aligned}$ & 484.905.000,00,- & 32,09 \\
\hline & 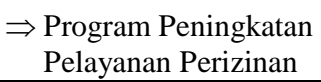 & 390.933.000,00,- & 25,87 \\
\hline & J u m l a h & $1.363 .914 .173,00$ & 100 \\
\hline
\end{tabular}

Jika dilihat dari Tabel 2 di atas tampak kelihatan, bahwa persentase antara Program Peningkatan Iklim Investasi dan Realisasi Investasi (32,09\%) yang berfokus pada penanaman modal, Program Peningkatan Pelayanan Perizinan $(25,87 \%)$ yang berfokus pada pelayanan terpadu khusus pemberian izin, dan Program Peningkatan Kapasitas Sumber Daya Aparatur $(1,88 \%)$ yang berfokus pada peningkatan sumber daya manusia kelihatan timpang dan tidak bersesuaian.

Upaya yang dilakukan oleh pimpinan dalam jajaran DPMPTSP Kabupaten Bulukumba diwujudkan dalam bentuk pendidikan dan pelatihan. Dalam bidang pendidikan, kepala dinas mendorong dan memotivasi para pejabat maupun staf ASN maupun Non ASN untuk melanjutkan pendidikan ke jenjang yang lebih tinggi, baik menggunakan biaya negara maupun biaya sendiri. Lebih jauh Kepala DPMPTSP Kabupaten Bulukumba mengatakan, bahwa saat ini kedudukan ASN maupun Non ASN dalam lingkup pemerintah daerah sangat kuat pengaruhnya dalam penyelenggaraan otonomi daerah, dan keberhasilan ataupun kegagalan kepala daerah dalam membangun daerahnya sangat tergantung dari kinerja pegawai. Adapun sumber daya manusia yang terdapat di Dinas Penanaman Modal dan Pelayanan Terpadu Satu Pintu di Kabupaten Bulukumba dapat dilihat pada tabel berikut ini:
Tabel 3. Daftar Eselonisasi Pada DPMPTSP Kabupaten Bulukumba

\begin{tabular}{llll}
\hline No. & Uraian & $\begin{array}{l}\text { Jenjang } \\
\text { Kepangkatan }\end{array}$ & Ket. \\
\hline 1. & Kepala Dinas & Eselon II/b & 1 Orang \\
2. & Sekretaris & Eselon III/a & 1 Orang \\
3. & Kepala Bidang & Eselon III/b & 4 Orang \\
4. & Kepala Sub Bagian & Eselon IV/a & 3 Orang \\
5. & Kepala Seksi & Eselon IV/a & 8 Orang \\
6. & Staf (ASN) & --- & 12 Orang \\
7. & Staf (Non ASN) & --- & 10 Orang \\
\hline Jumlah & 39 Orang \\
\hline \multicolumn{2}{l}{ Sumber : Absensi DPMPTSP Kab. Bulukumba, 2020 }
\end{tabular}

Dilihat dari tingkat pendidikan yang dimiliki para pegawai lingkup DPMPTSP Kabupaten Bulukumba, pada umumnya mereka mempunyai tingkat pendidikan yang baik.

Tabel 4. Tingkat Pendidikan Pada DPMPTSP Kabupaten Bulukumba

\begin{tabular}{lll}
\hline No. & Jenjang Pendidikan & Jumlah \\
\hline 1. & Strata 2 / S.2 & 8 Orang \\
2. & Strata 1 / S.1 & 24 Orang \\
3. & Diploma III / D.III & 2 Orang \\
$\mathbf{4 .}$ & SMA Setara & 3 Orang \\
$\mathbf{5 .}$ & SMP Setara & 1 Orang \\
\hline Jumlah & & 39 Orang \\
\hline Sumber : Absensi DPMPTSP Kab. Bulukumba, 2020
\end{tabular}

Dari Tabel 4 diatas dapat diketahui, bahwa dari total jumlah keseluruhan sebanyak 39 orang pegawai DPMPTSP Kabupaten Bulukumba, hal ini membuktikan bahwa, pada dasarnya organisasi perangkat daerah tersebut memiliki sumber daya manusia yang baik.

Meskipun DPMPTSP Kabupaten Bulukumba yang merupakan bagian dari institusi pemerintah dalam lingkup Pemerintah Daerah Kabupaten Bulukumba, namun dalam hal ini daya saing dalam diri pegawai/staf masih lemah dan harus terus ditingkatkan. Tingginya daya saing yang dimiliki oleh para staf dan pegawai dilingkup pemda akan memberikan dampak positif dalam tugas dan fungsi kinerja yang diberikan atasan. Dan hal ini yang penulis temukan dalam kehidupan sehari-hari dilingkungan kantor tersebut. Tingginya tingkat pendidikan yang dimiliki tidak diiringi dengan semangat dan etos kerja yang sering disampaikan oleh pimpinan dikantor.

Kinerja Pegawai Aparatur Sipil Negara (ASN) sering mendapat sorotan dari berbagai kalangan. Bahkan, berbagai media massa hampir setiap hari memberitakan tentang buruknya kinerja PNS. Alasan mendasar adalah para PNS dinilai kurang produktif, menghamburkan uang Negara, kurang disiplin serta rendahnya etos kerja. Dari pengamatan awal yang dilakukan di kantor DPMPTSP Kabupaten Bulukumba, masih dapat ditemui beberapa kendala yang dapat menunjukkan masih belum optimalnya efektivitas pelayanan publik. Hal itu dapat diindikasikan oleh beberapa kenyataan seperti program pelayanan publik yang ditetapkan tidak dapat mencapai hasil optimal, penggunaan/pemanfaatan sumberdaya organisasi untuk pelayanan publik belum maksimal, kemampuan organisasi untuk menanggapi perkembangan 
atau tuntutan masyarakat belum terwujud dengan optimal, dan tanggung jawab kepada masyarakat tentang penyelenggaraan pelayanan belum terwujud secara optimal. Sebagaimana diketahui bahwa, pengetahuan dan keterampilan cenderung lebih tampak (visible) dan relatif mudah untuk dikembangkan melalui program pelatihan. Untuk itu, DPMPTSP Kabupaten Bulukumba harus lebih sering mengirimkan pegawai untuk dibina dan dilatih baik melalui bimbingan teknis ataupun Forum Group Discussion (FGD).

Berdasarkan hasil penelusuran penulis selama melakukan penelitian yang dimulai dari bulan Februari hingga Mei 2020 serta mengambil data-data dan wawancara langsung dengan responden penelitian ini, diperoleh hasil-hasil yang kurang maksimal. Hasil kurang maksimal sebagaimana dimaksud adalah : (1) Terbatasnya tenaga operator yang menguasai teknologi informasi untuk aplikasi computer dalam bidang perizinan guna mengelola izin usaha, sementara banyaknya izin setiap hari yang harus diinput.; (2) DPMPTSP Kabupaten Bulukumba belum memiliki tenaga teknis yang khusus melakukan pemantauan di lapangan.; (3) Kurang memadainya sarana dan prasarana yang dimiliki dalam pengelolaan ijin usaha, dan hal ini sedikit menghambat proses penerbitan izin sehingga waktu yang dibutuhkan untuk menerbitkan izin usaha sesuai target tidak tercapai. Minimnya anggaran yang diberikan untuk pelaksanaan kegiatan ini yang hanya sebesar Rp. 28.364.000,00,$(1,88 \%)$ tidak mampu memberikan dampak maksimal terhadap kinerja pegawai.

Keberadaan motivasi dalam diri seseorang sangat penting, apalagi bagi ASN. Apabila motivasinya kuat ia akan tetap berusaha dan tidak putus asa saat mengalami kegagalan. Motivasi juga bisa disebut alasan yang terbentuk dari dua sumber yaitu : diri sendiri dan lingkungan atau faktor internal dan faktor eksternal.

Dalam hal sarana dan prasarana yang dimiliki oleh DPMPTSP Kabupaten Bulukumba, pada tabel 4.2 diperlihatkan bahwa Program Peningkatan Sarana dan Prasarana Aparatur menerima anggaran sebesar Rp. 188.101.500,- (12,45\%). Inipun dinilai masih kurang, mengingat banyaknya peralatan kantor yang sudah tidak berfungsi secara maksimal, disamping itu pula perlunya diadakan jaringan OSS serta pengadaan perangkat elektronik dan juga meubeler yang sudah tidak layak pakai. Jika dilihat dari target program kegiatan yang ingin dicapai organisasi ini, ketersediaan anggaran yang minim menyebabkan program kegiatan ini tidak berjalan secara efektif.

Namun terlepas dari persoalan tersebut, penulis menemukan ketimpangan dalam hal penganggaran di beberapa kegiatan. Dalam artian bahwa, ada beberapa kegiatan yang seharusnya mendapatkan porsi anggaran lebih banyak pada kegiatan namun tidak mendapatkan anggaran secara maksimal. Akibatnya, perencanaan yang seharusnya dapat diwujudkan ditahun berjalan tidak berjalan sesuai yang diharapkan.
Pada dasarnya Kepala DPMPTSP Kabupaten Bulukumba telah berupaya semaksimal mungkin guna menerapkan petunjuk dan peraturan sebagaimana yang diamanahkan dalam Undang-undang Nomor 5 Tahun 2014, bahwa pengembangan karir PNS dilakukan berdasarkan kualifikasi, kompetensi, penilaian kinerja, dan kebutuhan instansi pemerintah. Hal tersebut diwujudkan dengan mengikutkan beberapa pegawai/staf Aparatur Sipil Negara (ASN) pada kegiatan pendidikan dan Latihan (Diklat), Seminar, Kursus, maupun penataran yang pelaksanaannya dilakukan oleh pemerintah maupun swasta baik di dalam maupun diluar propinsi. Namun mahalnya biaya yang harus ditanggung oleh para peserta, sehingga pengiriman pegawaipun juga dibatasi.

Dalam hal peningkatan pelayanan pada para pelaku usaha dan masyarakat, yang berkaitan dengan pengembangan sumber daya manusia terkait perihal pengajuan permohonan ijin di DPMPTSP Kabupaten Bulukumba telah berupaya menggunakan suatu program aplikasi yang disebut Online Single Submission (OSS). Sebagaimana yang dikatakan oleh Kepala Bidang Perijinan dan Non Perijinan, bahwa OSS yang ada di DPMPTSP Kabupaten Bulukumba ini adalah suatu system yang dibuat oleh suatu lembaga OSS untuk dan atas nama bupati yang ditujukan kepada pelaku usaha melalui system elektronik yang terintegrasi. Namun meskipun demikian lanjut beliau, masih ada beberapa sektor tertentu yang mengharuskan perizinan usahanya diurus melalui dan diterbitkan oleh Badan Koordinasi Pasar Modal (BKPM) maupun instansi pemerintah lainnya yang berwenang tanpa melalui OSS. Seperti izin pada sektor keuangan, energi dan sumber daya mineral, real estate, dan izin yang berkaitan dengan perwakilan perusahaan asing.

Lebih jauh dikatakan oleh beliau, bahwa pada prinsipnya pelaksanaan pelayanan perizinan melalui OSS pada DPMPTSP Kabupaten Bulukumba sudah dilaksanakan sebagaimana yang diamanahkan Peraturan Pemerintah Nomor 24 Tahun 2018 tentang Pelayanan Perizinan Berusaha Terintegrasi Secara Elektronik namun belum berjalan secara maksimal sebagaimana yang diharapkan. Tidak berjalannya sistem ini secara maksimal disebabkan oleh beberapa hal, yaitu: (a) Saat ini DPMPTSP Kabupaten Bulukumba masih menggunakan sistem aplikasi sederhana dalam hal proses aplikasi perijinan lokal dan belum terkoneksi secara maksimal dengan sistem OSS, sementara untuk mengakses OSS secara maksimal dibutuhkan biaya yang tidak sedikit dan hingga saat ini belum adanya tersedia anggaran untuk kegiatan tersebut; (b) Mengingat OSS ini adalah suatu bentuk aplikasi yang masih baru dalam hal proses perizinan pada para pelaku usaha dan masyarakat, sehingga dibutuhkan adaptasi dan pengetahuan utamanya dalam bentuk pelatihan guna mengaplikasikan sistem tersebut. Disamping itu perlunya pula dilakukan koordinasi dan komunikasi dengan PTSP provinsi dan BKPM RI serta Badan Sandi Negara terekait izin akses dan pengkoneksian beberapa item, misalnya : e-signature 
(tandatangan digital); (c) Dalam hal sumber daya manusia yang dimiliki guna mengoperasikan OSS di DPMPTSP Kabupaten Bulukumba, saat ini sudah ada 3 orang staf/pegawai non ASN. Sementara untuk pengembangan sumber daya manusia itu sendiri harus berlatar belakang ASN dan hal ini menjadi problem tersendiri di OPD ini.

Sebagaimana diketahui, bahwa pentingnya daya saing yang dimiliki oleh sebuah lembaga akan berdampak pada banyaknya pelaku usaha dan masyarakat yang akan melakukan pengajuan ijin secara cepat dan tepat tanpa harus menunggu berlama-lama. Semakin tinggi daya saing yang dimiliki oleh organisasi ini, menunjukkan semakin tingginya pula produktivitas dari para pegawainya. Disamping itu jika daya saing yang dimiliki oleh organisasi ini semakin tinggi, nantinya akan berdampak positif terhadap para investor dan pelaku usaha untuk datang ke daerah menanamkan saham atau membuka usaha dagangnya. Dan jika DPMPTSP Kabupaten Bulukumba memiliki daya saing yang tinggi, maka peran serta pegawai/staf dalam mempertahankan kinerja yang dibebankan oleh atasan akan dapat terselesaikan dengan baik.

Sebagai suatu unsur yang dianggap mutlak dalam suatu organisasi terutama dalam lingkup instansi pemerintah, bahwa SDM harus memiliki peningkatan progress yang lebih baik kedepan. Memang diakui bahwa kemampuan manajerial tidak selalu ditentukan oleh latar belakang pendidikan. Namun akan lebih baik apabila, selain kemampuan manajerial juga dilengkapi dengan kemampuan teknis. Oleh karena dengan hanya sematamata mengandalkan kemampuan manajerial dan mengabaikan kemampuan teknis, operasionalisasi tugas tidak akan berjalan sebagaimana mestinya. Sebagaimana telah diatur di dalam Peraturan Pemerintah Nomor 100 tahun 2000 tentang pengangkatan Pegawai Negeri Sipil Dalam Jabatan Struktural, salah satu syarat yang harus dipenuhi oleh seorang pegawai negeri sipil untuk dapat diangkat dalam jabatan struktural adalah memiliki kemampuan manajerial dan kemampuan teknis fungsional.

Pelatihan dan pengembangan sumber daya manusia adalah hal penting yang harus dilakukan untuk mencapai tujuan organisasi. Di era globalisasi seperti ini semua orang dituntut untuk lebih canggih dalam menggunakan teknologi saat bekerja. Selain melakukan pelatihan dan pengembangan pegawai, Dinas Penanaman Modal dan Pelayanan Terpadu Satu Pintu Kabupaten Bulukumba juga harus menggunakan berbagai perangkat teknologi yang mendukung kemajuan dan perkembangan system pelayanan terpadu.

Dalam Peraturan Menteri Pendayagunaan Aparatur Negara dan Reformasi Birokrasi Republik Indonesia Nomor 38 Tahun 2017 tentang Standar Kompetensi Jabatan Aparatur Sipil Negara disebutkan Standar Kompetensi Jabatan Aparatur Sipil Negara yang selanjutnya disebut Standar Kompetensi ASN adalah deskripsi pengetahuan, keterampilan dan perilaku yang diperlukan seorang Aparatur Sipil Negara dalam melaksanakan tugas jabatan. Sesuai dengan pasal 16 Permenpa-RB No. 38/2017 disebutkan Standar Kompetensi ASN sebagaimana dimaksud menjadi acuan paling sedikit untuk : perencanaan aparatur sipil negara; pengadaan aparatur sipil negara; pengembangan karier aparatur sipil negara; pengembangan kompetensi aparatur sipil negara; penempatan aparatur sipil negara; promosi dan/atau mutasi aparatur sipil negara; uji kompetensi aparatur sipil negara; sistem informasi manajemen aparatur sipil negara; dan, kelompok rencana suksesi (talent pool) aparatur sipil negara.

Untuk itu kepala dinas selaku pimpinan tertinggi di organisasi ini harus berupaya semaksimal mungkin mencari solusi dalam hal penganggaran. Pembagian porsi anggaran pada setiap anggaran yang tertuang dalam Dokumen Pelaksanaan Anggaran (DPA) SKPD DPMPTSP Kabupaten Bulukumba harus diliat dari segi efektifitas penggunaannya yang sangat mendesak tanpa mengabaikan kegiatan lainnya. Hal ini bertujuan agar setiap pegawai dalam lingkup DPMPTSP dapat mengikuti diklat maupun seminar baik didalam maupun diluar propinsi.

Dalam hal pengembangan kompetensi sumber daya manusia yang ada di Dinas Penanaman Modal dan Pelayanan Terpadu Satu Pintu Kabupaten Bulukumba, hal ini erat kaitannya dengan sumber daya manusia yang unggul dan berdaya saing, serta perencanaan dan analisis kebutuhan sumber daya manusia. Untuk itu guna memaksimalkan pengembangan kompetensi SDM di DPMPTSP Kabupaten Bulukumba, adalah dengan memaksimalkan anggaran yang berfokus pada pelatihan dan pengembangan sumber daya manusia.

DPMPTSP Kabupaten Bulukumba sebagai sebuah organisasi perangkat daerah yang dibentuk dengan tujuan memberikan pelayanan perizinan bagi para pelaku usaha dan masyarakat, harus bekerja secara professional dalam memberikan pelayanan secara maksimal. Banyaknya keluhan serta lambatnya dalam proses pelaksanaan perizinan, ini tidak lepas dari skill dan sumber daya yang dimiliki oleh para pengelolanya.

Dalam pelaksanaan menuju organisasi yang berdaya saing handal tentu ada sektor - sektor yang di up untuk dapat mencapai tujuan. Dapat diketahui bahwa isu strategis di bidang sumber daya manusia, kesejahteraan dan kenyamanan pegawai dalam beraktifitas adalah Peningkatan Daya Saing Lembaga.

Peningkatan daya saing lembaga dapat terlaksana jika banyak hal atau sektor yang mendukung sehingga dapat bersaing dengan organisasi perangkat daerah lainnya yang ada di Kabupaten Bulukumba. Dengan keberadaan DPMPTSP Kabupaten Bulukumba mempunyai nilai daya saing dari beberapa opd lainnya, maka DPMPTSP Kabupaten Bulukumba dapat menjadi figur maupun acuan dalam tata kelola organisasi yang lebih baik. Hal - hal yang perlu diperhatikan dalam mencapai tujuan menjadi organisasi yang mempunyai daya saing antara lain : (1) Penganggaran kegiatan; (2) 
Sikap dan tingkah laku; (3) Penerimaan pegawai; (4) Perbaikan sistem perijinan; (5) Sarana dan prasarana

\section{KESIMPULAN DAN SARAN}

Kesimpulan hasil penelitian ini bahwa Dinas Penanaman Modal dan Pelayanan Terpadu Satu Pintu (DPMPTSP) Kabupaten Bulukumba sebagai garda terdepan dalam hal pemberian pelayanan secara maksimal pada para pelaku usaha dan masyarakat harus didukung dan ditopang dengan sumber daya serta sarana dan prasarana yang memadai. Dalam rangka peningkatan pelayanan yang lebih baik di masa yang akan dating perlu melakukan penataan ulang kembali Organisasi Perangkat Daerah terkait, mulai dari sarana prasarana hingga sumber daya manusia, utamanya memberikan pelatihan-pelatihan / bimbingan terkait dengan tupoksinya serta penganggaran sesuai kebutuhan dimaksud;

\section{DAFTAR PUSTAKA}

Armstrong, Michael. 1994. Manajemen Sumber Daya Manusia: A Handbook Of Human Resource Management. PT Elex Mediakomputindo. Jakarta.

Handayani, A., Hamka, H., \& Maldun, S. (2021). Analisis Pelaksanaan Pengembangan Sumber Daya Manusia Pada Kantor Dinas Kepariwisataan Kabupaten Kepulauan Selayar. Jurnal Paradigma Administrasi Negara, 2(2), 107-109.

Mitrani, A. 1995. Manajemen SDM Berdasarkan Kompetensi. Jakarta: Pustaka Utama Grafiti.

Peraturan Pemerintah Nomor 100 tahun 2000 tentang pengangkatan Pegawai Negeri Sipil Dalam Jabatan Struktural.

Peraturan Menteri Pendayagunaan Aparatur Negara dan Reformasi Birokrasi Republik Indonesia Nomor 38 Tahun 2017 tentang Standar Kompetensi Jabatan Aparatur Sipil Negara.

Peraturan Bupati Bulukumba Nomor 83 Tahun 2016 tentang Kedudukan, Tugas dan Fungsi, Susunan Organisasi, dan Tata Kerja Dinas Penanaman Modal dan Pelayanan Terpadu Satu Pintu Kabupaten Bulukumba.

Peraturan Bupati Bulukumba Nomor 88 Tahun 2015 tentang Penyelenggaraan Perizinan dan Non Perizinan Terpadu Satu Pintu Pemerintah Kabupaten Bulukumba;

Peraturan Bupati Bulukumba Nomor 49 Tahun 2017 perubahan atas Peraturan Bupati Nomor 88 Tahun 2015 tentang Penyelenggaraan Perizinan dan Non Perizinan Terpadu Satu Pintu Pemerintah Kabupaten Bulukumba.

Tobing. K. L, Diana Sulianti. 2009. Pengaruh Komitmen Organisasional dan Kepuasan Kerja Terhadap Kinerja Karyawan PT. Perkebunan Nusantara III di Sumatera Utara. Jurnal Manajemen Dan Kewirausahaan 11 (10), Maret 2009.
Robbins, Stephen P dan Timothy A. Judge. 2008. Perilaku Organisasi: Organizational Behaviour. Edisi 12. Salemba Empat. Jakarta.

Sugiyono. 2015. Metode Penelitian : Kuantitatif, Kualitatif dan R\&D, Bandung : Penerbit Alfabeta.

Suharsini Arikunto. 1993. Prosedur Penelitian : Suatu Pendekatan Praktek, Jakarta : Penerbit Rineka Cipta.

Sutrisno, Edy, (2010) Manajemen Sumber Daya Manusia, Kencana Prenada Media Group, Jakarta.

Winardi, J. 2008. Motivasi dan Pemotivasian dalam Manajemen.Yogyakarta: PT. Raja Grafindo Persada. 